\title{
Understanding Household Demand for Indoor Air Pollution Control in Developing Countries
}

\author{
by \\ Bruce A. Larson \\ University of Connecticut \\ Department of Agricultural and Resource Economics \\ 1376 Storrs Road, Unit 4021 \\ Storrs, CT 06269 \\ Email: bruce.larson@uconn.edu \\ Fax: +1-860-486-1932 \\ and \\ Sydney Rosen \\ Center for International Health \\ Boston University School of Public Health \\ 715 Albany St. T4W \\ Boston, MA, 02118 \\ Email: sbrosen@bu.edu
}

Revised April 2001

An earlier version of this paper was presented at the USAID/WHO Global Technical Consultation on the Health Impacts of Indoor Air Pollution and Household Energy in Developing Countries, May 3-4, 2000, Washington, DC, USA. The authors would like to thank, without implicating, the Editor, the journal reviewers, Jonathon Simon, Donald Thea, Randy Bluffstone, and the participants in the Technical Consultation for helpful comments and suggestions. Partial support for this analysis was provided by the Environmental Health Project II funded by the U.S. Agency for International Development. 


\title{
Understanding Household Demand for Indoor Air Pollution Control in Developing Countries
}

\begin{abstract}
More than 2 billion people rely on solid fuels and traditional stoves or open fires for cooking, lighting, and/or heating. Exposure to emissions caused by burning these fuels is believed to be responsible for a significant share of the global burden of disease. To achieve widespread health improvements, interventions that reduce exposures to indoor air pollution will need to be adopted and consistently used by large numbers of households in the developing world. Given that such interventions remain to be adopted by large numbers of these households, much remains to be learned about household demand for interventions designed (in part at least) to reduce indoor air pollution.

A general household framework is developed in Section 2 that identifies in detail the determinants of household demand for indoor air pollution interventions, where demand for an intervention is expressed in terms of willingness to pay. Household demand is shown to be a combination of three terms: (1) the direct consumption effect; (2) the child health effect; and (3) the adult health effect. While micro-level data are not available to estimate directly this model, existing data and information are used in Section 3 to estimate just the health effects component of household demand. Based on such existing information, it might be concluded that household demand should seemingly be strong given that willingness to pay, based on existing information, is seemingly large compared to costs for common interventions like improved stoves.

Given that household demand is not strong for existing interventions, this analysis shows that more clearly focused research on household demand for interventions is needed if such interventions are going to be demanded (i.e. adopted and used) by large numbers of households throughout the developing world. Four priority areas for future research are: (1) improving information on dose-response relationships between indoor air pollution and various health effects (e.g. increased mortality and morbidity risks); (2) improving information on impacts from interventions in terms of air pollution reductions and also cooking times, fuel use, and heat intensities; (3) improving information on household shadow values for improved health, with separate information for adult and child health; and (4) considering more directly household information, and its adequacy, for their ability to evaluate the relationships between fuel use and health.
\end{abstract}




\section{Understanding Household Demand for Indoor Air Pollution Control in Developing Countries}

\section{Introduction}

More than 2 billion people worldwide rely on solid fuels_-wood, charcoal, dung, crop residues, and coal—and traditional stoves or open fires for cooking, lighting, and heating. Solid fuels, while providing direct energy benefits to households, also impose on them a series of costs. One of the costs associated with solid fuels and traditional stoves stems from the very high levels of air pollution they generate. The health effects of high levels of indoor air pollution, such as higher mortality rates and increased risks of respiratory illness, fall mainly on children and women, who spend a good deal of time inside cooking and tending fires. Indoor air pollution from burning solid fuels is regarded as one of the most serious environmental problems facing developing countries (Smith et al. 2000; World Bank 1992), endangering the health of perhaps 400-700 million people. It is estimated to account for about 4 percent of the total burden of disease and 2.8 million premature deaths per year (Bruce et al. 2000). ${ }^{1}$ Two thirds of this total occurs in rural areas of developing countries, where the main source of pollution is smoke from fires and stoves, and another 23 percent is in urban areas of developing countries (WHO 1997; Reddy et al. 1997).

Smoke from the combustion of solid fuels contains a large number of potentially hazardous pollutants, including particulates, carbon monoxide, benzo[a]pyrene, formaldehyde, and nitrogen dioxide. Exposure to these pollutants, especially small particulates, is widely believed to be a risk factor for a number of health damages, including acute respiratory infections (ARI), chronic obstructive pulmonary disorder (COPD), cancers, cataracts, and low birth weight. To date, empirical studies have not defined the precise relationship between indoor emissions and health damages. Based on a number of observational studies in developing countries, however, it appears that young children in households that use solid biomass fuels are 2-3 times more likely to suffer ARI than children in households that use other fuels (Smith and Mehta 2000). Similarly, women who have cooked over biomass fires for fifteen years are 2-4 times more likely to develop COPD than are other women (Smith 1999). ${ }^{2}$

A number of interventions have been developed to reduce household exposure to indoor air pollution. The most widely-implemented is the introduction of improved stoves that emit fewer pollutants than traditional stoves. Other interventions include fuel-switching (e.g. from wood to coal or kerosene); improving household ventilation, fuel use practices, and cooking practices (i.e. lids on pots); and altering childcare practices to keep children away from the kitchen during cooking times. ${ }^{3}$

\footnotetext{
${ }^{1}$ This definition of indoor air pollution includes environmental tobacco smoke and other types of pollution as well as smoke from biomass and coal combustion.

2 The literature on the health effects of solid fuel use is reviewed in Smith and Mehta (2000) and in Bruce, PerezPadilla, and Albalak (2000).

${ }^{3}$ See Ballard-Tremeer and Mathee (2000) for a description of these interventions.
} 
Economic logic suggests that household demand for an intervention is equal to the household's willingness to pay for the intervention. If this willingness to pay, based on the household's perceived net benefits, is greater than the cost, a household will adopt (buy) the intervention. Given that some 300-400 million households have not yet adopted such interventions, ${ }^{4}$ it is reasonable to conclude that current household willingness to pay for available interventions is less than the current cost. Improving our understanding of household demand for such interventions remains a prerequisite for developing effective, large-scale policies and programs to reduce the impacts of indoor air pollution.

In the past decade, the literature on indoor air pollution and health-including analyses of the magnitude of the problem; the correlation among fuel use, air quality, and health; and the physical impacts of interventions (e.g. changed fuel efficiencies, cooking times, etc.)—-has grown rapidly. There has been little analysis to date, however, of household-level demand for indoor air pollution interventions. The public health officials, researchers, and program implementers working in the area of indoor air pollution abatement therefore lack a critical piece of information.

The purpose of this paper is to identify the determinants of household demand for interventions designed to reduce indoor air pollution The rest of the paper is organized as follows. Section 2 presents a microeconomic household framework that can be used to identify household demand for interventions that are designed to reduce indoor air pollution from burning solid fuels. Section 3 uses existing data from developing countries to demonstrate how the framework can be used to estimate key components of household demand related to adult and child health. ${ }^{5}$

The examples in Section 3 seem to suggest that household demand for interventions, based simply on their health impacts, should be strong. Given that many millions of households continue to rely on solid fuels and traditional stoves, it is clear that much remains to be learned empirically about household demands for interventions designed (at least in part) to reduce indoor air pollution. The paper concludes in Section 4 with a discussion of research that is needed if we are to strengthen household demand for interventions on a scale that is commensurate with the magnitude of the health burden.

\footnotetext{
${ }^{4}$ If we assume an average household size of 5-6, the 2 billion people estimated to be using solid fuels represent on the order of 300-400 million households.

${ }^{5}$ The direct consumption component is the focus of the literature on fuelwood collection and stove adoption. See, for example, Amacher, Hyde, and Joshee (1993) and Amacher, Hyde, and Kanel (1999). This literature is mainly concerned with the household impacts of fuel scarcity and/or the impacts of improved stoves on fuel collection and deforestation.
} 


\section{A Microeconomic Framework for Identifying Household Demands for Interventions}

When some intervention is adopted by a household to reduce indoor air pollution levels, such as a new stove, this adoption brings about a variety of changes in household activities and potentially in welfare. Such changes might include, for example:

- lower emissions and concentrations of indoor air pollutants, which could lead to reduced incidence of ARI, COPD, etc.;

- altered risk of burns and poisonings (e.g. from kerosene);

- changes in cooking practices that could alter women's and children's time in the kitchen;

- changes in the cost of cooking (e.g. by altering stove efficiency) that could change the amount of food prepared each day, the types of foods prepared, and the frequency of preparation;

- reallocation of women's and children's time spent on gathering fuels;

- reallocation of household income if money is spent or saved on the stove and fuel;

- shifts in other household production activities, such as agricultural production, and therefore in household income, due to the changes in fuel costs, time allocations, and labor productivity; and

- changes in medical expenditures to avoid and treat morbidity.

While adopting and using an intervention can induce many changes, the demand for an intervention is derived from the household's willingness to pay to obtain the welfare increase associated with adopting and using the intervention. Thus, to analyze household demand, a household welfare function is needed.

\subsection{An Expanded View of Household Welfare}

Economic models of households in developing countries usually begin with some notion of household welfare represented by a utility function, where utility is derived from consumption of various goods and services and leisure. Depending on the situation, some of these goods and services are purchased in local markets, and some are produced directly by the household.

To investigate health-related issues, it is necessary to consider an expanded form of a household utility function that includes specific health-related variables. As an example, consider a household with a utility function

$$
\mathrm{U}=\mathrm{U}(\mathrm{Ca}, \mathrm{Cc}, \mathrm{Cm}, \mathrm{L}, \mathrm{E}, \mathrm{P}, \mathrm{Hc}, \mathrm{Ha}) \text {, }
$$

where $\mathrm{Ca}$ is adult consumption of prepared foods; $\mathrm{Cc}$ is child consumption of prepared foods; $\mathrm{Cm}$ is household consumption of various market purchased goods; L is adult leisure time; $\mathrm{E}$ is energy produced from burning fuels; $\mathrm{P}$ is pollution inside the home; $\mathrm{Hc}$ is child health; and $\mathrm{Ha}$ is adult health. 
These eight variables were chosen to cover a wide range of possibilities that are incorporated to varying degrees in the health economics literature and the literature on agricultural production in developing countries. The agricultural household literature usually focuses on food consumption, consumption of market purchased items, fuel use, and leisure, although the explicit relationship between raw foods and prepared foods is not usually considered (see, e.g., Amacher, Hyde, and Kanel 1999; de Janvry, Fafchamps, and Sadoulet 1990; Singh, Squire, and Strauss 1986). The health economics literature typically assumes that utility depends on health, leisure, and other consumption of market goods (e.g., see Harrington and Portney 1987; Alberini and Krupnick 1999; Grossman 1972; and Jacobson 2000).

In the above formulation of the household utility function, prepared foods and fuel use affect household welfare (utility) through several channels. Prepared foods affect utility in two ways: directly, as a final consumption item for adults and children; and indirectly, as an input into the health of children and adults. Fuel use affects household welfare through five different paths: (1) by providing energy for the production of prepared foods, which then affect utility directly; (2) by providing energy for the production of prepared foods, which affect health and then utility; (3) by generating indoor air pollution, which affects health and then utility; (4) by providing energy for services, such as warmth and light, that are directly valued by the household; and (5) by generating emissions that might negatively affect household utility in ways not related to health. For example, biomass smoke could be an eye irritant that households dislike, independent of any health concerns. It is not necessary that all five effects exist for all households in all locations, but the possibilities are included here for completeness.

\subsection{Adding Indoor Air Pollution Interventions to the Household Utility Function}

Given the household utility function described above, we must now identify how an indoor air pollution intervention affects household welfare. For the purposes of this paper, indoor air pollution interventions are organized into two categories: (1) fuel efficiency interventions that allow the same amount of energy to be produced with less fuel (i.e., increases in a fuel efficiency parameter denoted as \$); and (2) emission/concentration/exposure reduction interventions that reduce the amount of emissions per unit of fuel used (i.e., reductions in an emissions intensity parameter denoted as "). Emissions reduction interventions in this framework include improved stoves with and without chimneys, alternative fuel combinations, improved ventilation, and placement of stoves/fires/kitchens. The same interventions that reduce emissions can also affect the efficiency with which fuel is converted into heat and heat is transferred to the food. Even if the primary objective of the intervention is to lower emissions, the fuel efficiency consequences must be incorporated into the analysis to understand the overall household benefits.

In this model, households are assumed to maximize their welfare subject to various constraints. These constraints usually involve monetary and time endowments, other exogenous factors, production technologies, and income. For example, household agricultural production constraints include production of some crop (a staple such as maize, cassava, rice, and/or millet) as well as 
the gathering of fuel. ${ }^{6}$ These items are produced and consumed by the household, and any surplus not consumed by the household may be sold on a local market. In some settings, local markets do not exist for a product, so that household production must equal consumption of the item (e.g. households are often self-sufficient in producing and consuming fuelwood). Inputs into these production constraints can include land, women's labor inputs, and access to fuel sources.

The household is also constrained by its time endowment, which for our purposes is women's time. Available female time is allocated to four main uses: fuel collection, crop production, cooking time, and other activities (other domestic tasks, child care not during cooking, etc.). Some activities, such as fuel gathering and child minding, might be jointly accomplished. The household is constrained in that these four uses of time (the household's demand for labor) must equal its available time (its supply of labor).

Women and children in a household consume a number of goods, such as the staple crop, fuel, market-purchased consumer goods, and perhaps healthcare services. If household demand for the staple is less than household production of the staple, the household has net sales and additional cash income (and vice versa). If the gathered fuel is a non-marketed item, household fuel gathering must equal household demand for fuel. If well-functioning markets for fuels and women's labor do not exist, the household's shadow prices for fuel and women's time must adjust so that demand for these items equals supply. ${ }^{7}$

In making these consumption decisions, households face a cash constraint. In this simple framework, expenditures on market-purchased consumer items and health services must equal any non-labor exogenous income, denoted as $\mathrm{S}$ (e.g. cash transfers from a relative in a city) plus net market sales/purchases of the food crop. Total household income is then equal to household cash profits from agricultural activities plus any off-farm wage income plus any non-labor income S. This budget constraint is binding so that total income equals total expenditures.

Assuming a household has maximized its welfare given the various production, time, endowment, and income constraints, the household's level of utility can be written as:

$$
\mathrm{U}^{*}=\mathrm{U}\left(\mathrm{Ca}^{*}, \mathrm{Cc}^{*}, \mathrm{Cm}^{*}, \mathrm{~L}^{*}, \mathrm{E}^{*}, \mathrm{P}^{*}, \mathrm{Hc}^{*}, \mathrm{Ha}^{*}\right),
$$

where $\mathrm{U}^{*}$ is the maximized level of welfare and the "**" notation denotes the optimal levels of each item in the household welfare function. All the household's constraints are binding, so that these optimal values depend on all the exogenous or fixed factors in the household's decision problem. In our model, these factors are the parameter ", representing the emissions intensity of fuel used in the household (e.g. grams of $\mathrm{PM}_{10}$ per $\mathrm{kg}$ of wood); the parameter \$, representing the energy intensity of fuel used in the household; S, representing exogenous income (i.e. transfers);

\footnotetext{
${ }^{6}$ HOW IS CROP PRODUCTION AND FUEL GATHERING A “CONSTRAINT”? CLARIFY WORDING.

7 For more on such non-separable models with missing markets, see Singh, Squire and Strauss (1986) and de Janvry, Fafchamps, and Sadoulet (1990).
} 
and Z, representing all other fixed parameters influencing household choices (e.g. fixed prices, technologies, preferences, time endowments, local infrastructure, etc.).

Since all the optimal choices depend on these fixed factors ", \$, S, and Z, the welfare function can be written simply as:

$$
\mathrm{U}^{*}=\mathrm{V}(", \$, \mathrm{~S}, \mathrm{Z})
$$

where $\mathrm{U}^{*}$ is the maximized level of household utility given all the exogenous or fixed factors in the household decision problem. The function V is called an 'indirect' utility function.

\subsection{Deriving Household Demand for an Intervention}

Let us start by considering an intervention designed to reduce indoor air pollution (say an improved stove) that changes $\$$ and ", say from $\$ 0$ to $\$ \mathrm{n}$ and "o and " $\mathrm{n}(\mathrm{o}=$ old and $\mathrm{n}=$ new levels). From the household's perspective, household demand is defined by its willingness to pay for the intervention (Harrington and Portney, 1987). The household compares its demand, represented by willingness to pay, to retail price to determine if the household should purchase (adopt and use) the intervention. The household follows this same logic even if the intervention is provided for free (it still decides if its willingness to pay is greater than zero) ${ }^{8}$.

In general, willingness to pay is the monetary equivalent of the welfare impact of using the intervention. Using the above notation, the welfare impact of the intervention is just the change in utility ) $\mathrm{U}^{*}=\mathrm{V}(\$ \mathrm{n}$, , n; Z, S $)-\mathrm{V}(\$ \mathrm{o}$, " o; Z, S $)$, where again $\mathrm{Z}$ represents all other parameters of the problem except exogenous income, $\mathrm{S}$ is exogenous income, and ) $\mathrm{U}^{*}$ is the change in welfare. Since exogenous income $S$ and other factors $\mathrm{Z}$ are fixed, they do not change with the intervention. The household's total income, based on production and income levels does change, but the exogenous portion of total income, $\mathrm{S}$, does not.

This welfare change, ) $U^{*}$, takes into account all adjustments in the household induced by the intervention. If the intervention involves large changes to \$ and ", it might be expected that these other household adjustments—-such as adjustments in women's time allocations or fuel use-are also large. These adjustments are all included in the welfare change ) U*.

Since ) U* is in "utility" or "welfare" terms, it cannot be estimated directly. From the

\footnotetext{
${ }^{8}$ CAN WTP BE $<0$ ? IF AN INTERVENTION IS FREE BUT THE HOUSEHOLD PERCEIVES INDIRECT COSTS (E.G. LONGER COOKING TIMES), THEN IS WTP NEGATIVE? (I.E. THEY'D PAY NOT TO HAVE THE INTERVENTION.)

${ }^{9}$ BELIEVE IT OR NOT, I STILL DON'T UNDERSTAND THIS. IN THE EQUATION IN THE PREVIOUS PARAGRAPH, DELTA U* REFLECTS ONLY DIFFERENCES IN ALPHA AND BETA,WHICH ARE TECHNOLOGICAL PARAMETERS OF FUEL AND EMISSIONS EFFICIENCIES. HOW DO THESE INCORPORATE ALL THE OTHER HOUSEHOLD ADJUSTMENTS? (WHICH MIGHT BE THE SAME AS ASKING WHY Z IS FIXED.)
} 
household's perspective, however, the monetary equivalent of this welfare change (call it $\mathrm{B}^{*}$ ) can be defined implicitly as $\mathrm{V}\left(\$ \mathrm{n}\right.$, " $\left.\mathrm{n} ; \mathrm{Z}, \mathrm{S}-\mathrm{B}^{*}\right)=\mathrm{V}(\$ o$, "o; Z, S $)$, so that

$$
\mathrm{B}^{*}=\mathrm{B}(\$ o, " \mathrm{o}, \$ \mathrm{n}, " \mathrm{n} ; \mathrm{Z}, \mathrm{S})
$$

The amount B* is the household's demand for the intervention, where again the correct measure of demand is willingness to pay to adopt the intervention and obtain the welfare change. ${ }^{10}$ As common with any demand framework, willingness to pay $\mathrm{B}^{*}$ can be compared to the price of the intervention (e.g. the market price of an improved stove) to evaluate whether the household has the incentive to adopt the intervention. ${ }^{11}$

While the measure $\mathrm{B}^{*}$ is a correct measure of the household demand for an intervention, it tells us little about the determinants of demand. To provide a better understanding of $\mathrm{B}^{*}$, and thus of household demand for indoor air pollution interventions, the household welfare function can be used to decompose the welfare change ) $\mathrm{U}^{*}$ and the monetary equivalent $\mathrm{B} *$ into three components that can be more easily interpreted and estimated (or approximated).

To begin, consider an intervention that reduces the emissions intensity of fuels used by a small amount, so that the parameter " decreases by a small amount (and fuel efficiency $\$$ remains constant). Using the utility function $\mathrm{U}^{*}=\mathrm{V}(", \$, \mathrm{~S}, \mathrm{Z})=\mathrm{U}\left(\mathrm{Ca}^{*}, \mathrm{Cc}^{*}, \mathrm{Cm}^{*}, \mathrm{~L}^{*}, \mathrm{E}^{*}, \mathrm{P}^{*}, \mathrm{Hc}^{*}\right.$, $\mathrm{Ha}^{*}$ ), the change in utility from a small change in ", denoted as ) $\mathrm{U}^{*} /$ ) ", depends simply on how the change in $\alpha$ affects the optimal levels of the eight items in the utility function. Thus,

$$
\begin{aligned}
& \text { ) } \left.\left.\left.\left.\mathrm{U}^{* / /} \text { " = () } \mathrm{U}^{* / /}\right) \mathrm{Hc}^{*}\right)() \mathrm{Hc}^{* / /}\right) "\right)+ \\
& \text { () } \left.\mathrm{U}^{* / /} \mathrm{Ha}^{*}\right)\left(\text { ) } \mathrm{Ha}^{*} /\right) \text { ") }+ \\
& \text { () } \left.\left.\left.\left.\left.\left.\mathrm{U}^{*} /\right) \mathrm{Ca}^{*}\right)() \mathrm{Ca}^{*} /\right) \text { ") +() } \mathrm{U}^{* /}\right) \mathrm{Cc}^{*}\right)() \mathrm{Cc} * /\right) \text { ") + } \\
& \text { () } \left.\left.\left.\mathrm{U}^{* /} / \mathrm{Cm}^{*}\right)() \mathrm{Cm} * / \text { ) ") +() } \mathrm{U}^{* /} /\right) \mathrm{P}^{*}\right)() \mathrm{P}^{*} / \text { ) "). }
\end{aligned}
$$

While a rather long expression, the increase in the optimal level of utility from a small decrease in emissions intensity , ) $U^{*} /$ ) ", is in fact just a combination of three effects: the direct child health effect, defined as () $\left.\left.\left.\mathrm{U}^{* /} /\right) \mathrm{Hc}^{*}\right)() \mathrm{Hc} * /\right)$ "); the direct adult health effect, defined as () $\mathrm{U}^{* /} / \mathrm{Ha} \mathrm{Ha}^{*}() \mathrm{Ha}^{*} /$ ) "); and the direct consumption effects, which are the final four terms identified above. $^{12}$

\footnotetext{
${ }^{10}$ More specifically, $\mathrm{B} *$ is a measure of compensating variation.

${ }^{11}$ While theoretically correct, the benefits measure $\mathrm{B} *$ is not directly observable. It can be investigated empirically, however, using surveys and contingent valuation methods (see, e.g., Hammitt 2000; Weaver, et al. 1996; Lui, et al. 2000).

12 This expression is the result of applying the Envelope Theorem (e.g. Roy's Identify and Hotelling's Lemma) from the mathematics of constrained optimization. As a result, because leisure and energy produced are not directly a function of air emissions, there are no direct consumption effects related to these terms. Depending on the situation, it is also likely
} 
These consumption effects--the direct effects on the household that are not due to health impacts--have been studied to some degree in the previous literature. ${ }^{13}$ The remainder of this paper therefore focuses on the direct adult and child health effects.

Since ) $\mathrm{U}^{*} /$ ) " is a welfare change, it is not possible to estimate its value directly. Using the notion of the marginal utility of income, denoted as ) $\mathrm{U}^{*} /$ ) $\mathrm{S}$ where $\mathrm{S}$ is exogenous income, the monetary equivalent of this welfare change is:

$$
\text { ) } \left.\left.\mathrm{S} /)^{\prime}=\left(() \mathrm{U}^{*} /\right) "\right) /\left(() \mathrm{U}^{*} /\right) \mathrm{S}\right)
$$

This marginal willingness to pay $\Delta \mathrm{S} /$ ) " is simply one point on the household's demand schedule of changes in emissions intensity. Focusing on just the child and adult health components specified above, it is possible to write this marginal willingness to pay as:

$$
\begin{aligned}
& \text { ) } \left.\left.\left.\left.\left.\left.\mathrm{S} /) \alpha=\left[() \mathrm{U}^{*} /\right) \mathrm{Hc}^{*}\right) /\left(() \mathrm{U}^{*} /\right) \mathrm{S} \text { )] () } \mathrm{Hc}^{*} /\right) \alpha\right)+\left[() \mathrm{U}^{*} /\right) \mathrm{Ha}^{*}\right) /\left(\text { ) } \mathrm{U}^{*} /\right) \mathrm{S} \text { )] () } \mathrm{Ha}^{*} /\right) \alpha\right) \\
& \left.\left.\left.\left.=\left[\mathrm{Pc}^{*}\right]() \mathrm{Hc}^{*} /\right) \alpha\right)+\left[\mathrm{Pa}^{*}\right]() \mathrm{Ha}^{*} /\right) \alpha\right)
\end{aligned}
$$

where the terms in square brackets [] are the household's shadow value of child and adult health, denoted simply as $\mathrm{Pc}^{*}$ and $\mathrm{Pa}^{*}$.

Harrington and Portney (1987) provide a concise explanation of household shadow values for health. For the household framework investigated here, the household's shadow value for adult health, $\mathrm{Pa}^{*}$, is somewhat complicated. Adults are income earners in general, whether this income is in wage labor, agricultural production, or household activities such as child care. Adult health is also likely to influence child health through a variety of channels. The shadow price of adult health, $\mathrm{Pa}^{*}$, can therefore contain five terms: 1) an adult "pain and suffering" effect; 2) savings on avoidance expenditures; 3) savings on adult medical expenses; 4) increased household production generated by healthy adults; and 5) the indirect effect of adult health on child health. Note that for item (4) above, this additional household production can be in terms of more agricultural output, more off-farm labor, more child care, etc. Similarly, the household shadow value for child health, $\mathrm{Pc}^{*}$, can clearly contain the first four terms above. ${ }^{14}$ In some situations it might be possible to estimate $\mathrm{Pc}^{*}$ and $\mathrm{Pa}^{*}$ directly, while in other situations it should be possible to estimate some of the components of $\mathrm{Pc}^{*}$ and $\mathrm{Pa}^{*}$.

that some of the direct consumption effects would also be zero. They are included in the text to recognize the possibility. For energy efficiency improvements, energy produced is a function of energy efficiency, so that an intervention affecting energy efficiency would have an additional consumption effect for the household.

${ }^{13}$ THEY HAVE? NEED A SOURCE OR EXPLANATION HERE.

${ }^{14}$ HOW CAN IT CONTAIN TERM (3) (SAVINGS ON ADULT MEDICAL EXPENSES)? 
In an identical fashion, the health benefits to the household from an energy efficiency improvement would be:

$$
\text { ) } \left.\left.\left.\mathrm{S} /) \beta=\left[\mathrm{Pc}^{*}\right]() \mathrm{Hc}^{* / /} \beta\right)+\left[\mathrm{Pa}^{*}\right]() \mathrm{Ha}^{*} /\right) \beta\right) \text {. }
$$

If an intervention simultaneously affects fuel efficiency (say ) \$) and indoor air emissions (say ) "), which will often be the case, total household willingness-to-pay for the intervention (the benefits) is simply the sum of the two individual benefits, so that:

$$
\begin{aligned}
\mathrm{B}^{*}= & {\left.\left.\left.\left.\left[\mathrm{Pc}^{*}() \mathrm{Hc} * /\right) \alpha\right)+\mathrm{Pa}^{*}() \mathrm{Ha}^{* / /} \alpha\right)\right]\right) \alpha+} \\
& {\left.\left.\left.\left.\left.\left[\mathrm{Pc}^{*}() \mathrm{Hc} /\right) \beta\right)+\mathrm{Pa}^{*}() \mathrm{Ha}^{*} /\right) \beta\right)\right]\right) \beta }
\end{aligned}
$$

This decomposition of household demand allows us to consider separately the household's shadow values for health and the change in health from the intervention. The health effects from the intervention must be estimated from some health-related production function (e.g. a doseresponse relationship), while the shadow values can be estimated using various valuation methods. This definition of demand also provides the theoretical foundation for estimating household demand for interventions and for understanding how policy, market, and household conditions affect the magnitude of these benefits. ${ }^{15}$

\section{Estimating the Health Components of Household Demand Using Existing Data}

If we are to improve our understanding of household demand for indoor air pollution interventions, future research should focus on estimating household demand, based on the measure $\mathrm{B}^{*}$ outlined above, in diverse locations in developing countries. Without further data on demand, we will not be able to solve the problem of how to increase $\mathrm{B}^{*}$ for large numbers of households in the developing world and thus generate large-scale demand for interventions. This section uses available information on indoor air interventions, health effects, and household shadow values to show how to estimate household demand for indoor air pollution interventions and to begin to evaluate the quality of existing information.

Four types of information are needed to estimate the health components of household demand:

i. the intervention's impacts on fuel efficiency and emissions () " and ) \$) and the resulting effect on indoor air concentrations;

ii. the specific health impacts Hc and Ha to be included in the analysis (e.g. decreased mortality risks or decreased ARI cases, as well as baseline values);

\footnotetext{
${ }^{15}$ The above expression for B* assumes, implicitly, that the household's shadow values for improved health are constant over the changes ) " and ) \$. This assumption is standard in the literature (e.g. see Viscusi 1993). More recently, Hammitt (2000) suggests that this assumption is correct.
} 
iii. the dose-response relationships that link ) " and ) \$ to direct health changes ) Hc and ) $\mathrm{Ha}$; and

iv. estimates of the household's shadow prices $\mathrm{Pc}^{*}$ and $\mathrm{Pa}^{*}$ for changes in child and adult health.

Note that this list does not include the effects of adult health on child health. We have omitted this component of demand here because, to our knowledge, no data are available that would allow us to estimate it.

Some data are available on the effects of interventions on indoor particulate concentrations (item i above) and on the health impacts and baseline values (item ii). There is so far almost no published work, however, on dose-response relationships for well-defined health impacts at the concentrations seen inside houses in developing countries (item iii). ${ }^{16}$ Household shadow prices for health improvements and risk reductions (item iv) have been estimated, though extrapolating from one local situation to another (the "benefits transfer" approach) poses difficulties. Table 1 provides some examples of the value of specific health outcomes in developing countries, while Table 2 lays out three examples of estimating the direct health components of the benefits measure $\mathrm{B}^{*}$ from improved stove interventions.

In Table 2, the columns "traditional" and "improved" are based on Bruce (1999), who reports that total suspended particulate (TSP) concentrations tend to range from $3,140-6,400 \mu \mathrm{g} / \mathrm{m}^{3}$ during cooking using traditional methods but fall to between 1,113-4,600 $\mu \mathrm{g} / \mathrm{m}^{3}$ with improved stoves. Let us consider an example in which TSP levels are $4,500 \mu \mathrm{g} / \mathrm{m}^{3}$ with a traditional method and $2,000 \mu \mathrm{g} / \mathrm{m}^{3}$ with an improved stove. In this case, the intervention generates a $2,500 \mu \mathrm{g} / \mathrm{m}^{3}$ reduction in TSP levels during cooking. If these concentrations lasted for six hours of daily cooking time, and the background level during the remainder of the day were around $100 \mu \mathrm{g} / \mathrm{m}^{3}$, then a daily average TSP level would be about $1,200 \mu \mathrm{g} / \mathrm{m}^{3}$ for the traditional method of cooking and about $575 \mu \mathrm{g} / \mathrm{m}^{3}$ with the improved stove. If $\mathrm{PM}_{10}$ comprised 30 percent of TSP, then average daily $\mathrm{PM}_{10}$ levels would be about $360 \mu \mathrm{g} / \mathrm{m}^{3}$ with the traditional method and about 172.5 $\mu \mathrm{g} / \mathrm{m}^{3}$ with the improved stove. Assuming that each day of the year is identical in terms of cooking duration, then annual average $\mathrm{PM}_{10}$ levels would also be $360 \mu \mathrm{g} / \mathrm{m}^{3}$ with the traditional method and about $172.5 \mu \mathrm{g} / \mathrm{m}^{3}$ with the improved stove. Though these levels far exceed WHO and US EPA standards, comparable ambient annual average concentrations have been reported and/or estimated in parts of large cities in developing countries with high pollution levels.

\section{Valuing Mortality Risk Changes}

Increased mortality risk is a standard concern for $\mathrm{PM}_{10}$ (e.g., Schwartz 1994). For this example, let us define the health unit of interest as annual average mortality risk to children and adults. With mortality risk as the health unit, information is now needed on the relationship between

\footnotetext{
${ }^{16}$ See the discussion in Smith and Mehta (2000). Forthcoming work by Ezzati and Kammen (2000) may begin to address this problem.
} 
$\mathrm{PM}_{10}$ concentrations and mortality risk.

The literature on the health effects of air pollution provides clear evidence of increased mortality risks from inhalation exposure to particulates (e.g.,Wilson and Spengler 1996). Epidemiological studies conducted under wide-ranging conditions (environmental, climatic, demographic, and geographic) consistently indicate that roughly a 1 percent increase in total daily mortality occurs for every $10 \mu \mathrm{g} / \mathrm{m}^{3}$ of $\mathrm{PM}_{10}$ in ambient air (Dockery and Pope 1996), with a range of 0.7-1.1 suggested by the literature (e.g. Schwartz 1994). In a developing country context, Ostro et al. (1996) obtained essentially the same result for Santiago, Chile. Using this information, Larson et al. (1999) developed an initial particulate coefficient (PC) equal to $8.5^{*} 10^{-6}$ to estimate the additional annual mortality risk per person per year per $1 \mu \mathrm{g} / \mathrm{m}^{3}$ of $\mathrm{PM}_{10}$. To our knowledge, there are no separate estimates for children and adults available in the literature. The same particulate coefficient must therefore be used for children and adults alike. ${ }^{17}$ Again, we emphasize here that this number is based on existing information from ambient studies. There is no comparable published work on such a mortality PC at concentrations seen inside houses in developing countries.

Using the above particulate coefficient, if the intervention reduces $\mathrm{PM}_{10}$ concentrations from 360 to $172.5 \mu \mathrm{g} / \mathrm{m}^{3}$, a change of $187.5 \mu \mathrm{g} / \mathrm{m}^{3}$, mortality risk per person per year would be estimated to fall by $187.5^{*} 8.5^{*} 10^{-6}=-0.0016$. If baseline total annual mortality risks were, for example, around 0.015 (a 1.5 percent annual chance of death on average in the population), the stove intervention would be expected to lead to roughly a 10 percent reduction in total annual mortality risk for both adults and children in the household.

\section{Household Shadow Values Pc* and Pa* for Mortality Risks}

The next step in the analysis is to determine the household's shadow prices for improved health (denoted above as $\mathrm{Pa}^{*}$ and $\mathrm{Pc}^{*}$ ), which in this example are essentially the household's annual willingness-to-pay for the estimated reduction in annual mortality risk. A large number of studies have attempted to estimate the value of mortality risk, although usually in developed countries. ${ }^{18}$ These empirical estimates of the "value of a statistical life" (VOSL) are simply an extrapolation of

\footnotetext{
${ }^{17}$ The average dose-response parameter cited in the text ( 1 percent increase in daily deaths per $10 \mu \mathrm{g} / \mathrm{m}^{3}$ increase in $\mathrm{PM}_{10}$ ) is based on epidemiological studies conducted primarily in the U.S. With about 2,100,000 total deaths in the U.S. annually, there are on average 5,753 deaths per day. A one-percent increase in daily deaths equals 57.53 additional deaths per day. If the entire U.S. population of approximately 250,000,000 individuals were exposed to an additional 10 $\mu \mathrm{g} / \mathrm{m}^{3}$ of $\mathrm{PM}_{10}$ daily, then the estimated additional risk of death per day per person would be $57.53 / 250,000,000=$ $2.3^{*} 10^{-7}$. Multiplying this daily effect by 365 to convert it to an annual effect, the resulting individual annual particulate mortality coefficient (PC) is $8.5^{*} 10^{-5}$ per $10 \mu \mathrm{g} / \mathrm{m}^{3}$ of $\mathrm{PM}_{10}$, or equivalently $8.5^{*} 10^{-6}$ per $1 \mu \mathrm{g} / \mathrm{m}^{3}$ of $\mathrm{PM}_{10}$ assuming linearity in the particulate dose-response function. This number is used in the text solely as an example. Separate estimates for children and adults could be based on different mortality risks at different ages, while assuming that the basic 1 percent increase in daily mortality per $10 \mu \mathrm{g} / \mathrm{m}^{3}$ increase in $\mathrm{PM}_{10}$ remained the same. Given that death rates are higher in developing countries than developed countries, using developing country deaths rates just makes the particulate coefficient larger.

${ }^{18} \mathrm{~A}$ thorough review of the theory and empirical results is provided in Viscusi (1993).
} 
an estimated willingness-to-pay for a marginal change in mortality risk (i.e. the value of a .001 reduction in risk is multiplied by 1000 to come up with the VOSL). Unfortunately, it can often be difficult to determine the underlying marginal risk changes associated with the VOSL estimates reported in the literature. For example, a typical VOSL estimate for the U.S. is $\$ 3$ million. What this might actually mean, however, is that people in the study sample were willing to pay an average of $\$ 3,000$ for a 0.001 reduction in annual mortality risk (and not that they valued an actual life at $\$ 3$ million).

To translate a VOSL estimate from one country to another, it has become common practice to weight the VOSL by the income ratio between the country in which the VOSL was estimated and the new country. Many of the VOSL estimates provided in Viscusi (1993) were estimated for samples of individuals in the U.S. with average annual incomes of around $\$ 40,000$. If a typical household in a developing country had an income equivalent of, say, $\$ 300$, the income ratio would be about 0.008 . Using this ratio as a weight, then the developed country figure of $\$ 3,000$ for a 0.001 reduction in annual mortality risk would be the equivalent of $\$ 22$ for the low-income developing country household. ${ }^{19}$

With an estimated annual mortality risk reduction of 0.0016, and an estimated willingness-to-pay of $\$ 22$ for each 0.001 reduction in mortality risk, the estimated annual benefit per person in the household would be estimated at about $\$ 36$. If all five people in our hypothetical household were exposed to such $\mathrm{PM}_{10}$ levels, then the household willingness to pay would be $\$ 143$ per year. If this figure were in the neighborhood of the real WTP, the household demand based on willingness to pay would be substantially higher than the typical annual costs of improved stoves, which are reported to be in the range of \$8-21 for an improved stove with chimney (Ballard-Tremeer and Mathee 2000).

The simple benefits transfer logic described above is dubious for at least two reasons, even if we assume that households fully understand the risk reduction from the intervention. First, households in developing countries face multiple health risks, from air, water, pests, accidents, poor nutrition, etc. As Dickie and Gerking (1991) show, it could be the case that how a household values one type of risk reduction depends fundamentally on the other types of health risks confronting households. When taking into account multiple risks, Dickie and Gerking (1991) estimate daily marginal willingness-to-pay to avoid symptoms related to outdoor air pollution of just $\$ 1$ for a data set from California, while estimates that do not take into account multiple risks are more than $\$ 20$ per day (and sometimes over $\$ 100$ per day).

Second, using an income ratio to weight the original value assumes that the income elasticity for health risk reductions equals 1 , so that a 100 percent increase in income generates a 100 percent

\footnotetext{
${ }^{19}$ We have not found any separate estimates reported in the literature of parents' willingness-to-pay for mortality risk reductions for their children. A recent study by Lui et al. (2000) does consider the issue in relation to a mild illness ( a cold), but not for mortality risk. For this example, we therefore assume that the monetary value of the risk reduction is identical for children and adults.
} 
increase in WTP. Mathematically, this means that WTP $=\mathrm{A}(\mathrm{a}) \mathrm{Y}^{\mathrm{a}}$, where $\mathrm{a}$ is the income elasticity and $\mathrm{A}(\mathrm{a})$ is a parameter that depends on the income elasticity a and the base-case WTP for the high income country (the base from which the transfer is being made). If $0<a<1$, health is a "normal" good, and WTP at lower levels of income is higher than estimated by the simple income ratio approach. If a $>1$, so that health is a "superior" good, then WTP at lower levels of income should be lower than estimated by the simple income ratio approach. The implications of this income elasticity are enormous. If $a=1$, a benefits transfer using an income ratio of $\$ 40,000 / \$ 300$ implies that the household value is $\$ 22$. If a $=0.5$, however, the benefits transfer implies a household value of $\$ 260$ (which is almost the total annual household income). On the other hand, if $\mathrm{a}=1.3$, the benefits transfer implies a value of just $\$ 5.2$ (and if $\mathrm{a}=1.5$, then this value falls to just $\$ 2$ !).

\section{Examples from Guatemala and Kenya}

The right half of Table 2 (labeled "Plancha" and "Kenya") provides calculations similar to those above using information reported in studies of improved stoves in Guatemala and Kenya. In Guatemala, monitored daily average $\mathrm{PM}_{2.5}$ levels were about $1,100 \mu \mathrm{g} / \mathrm{m}^{3}$ with a traditional threestone fire and about $180 \mu \mathrm{g} / \mathrm{m}^{3}$ with an improved stove (the "Plancha"). While a separate $\mathrm{PM}_{2.5}$ particulate coefficient for mortality risks is not available, we should expect it to be larger than the $8.5^{*} 10^{-6}$ particulate coefficient used to estimate the additional mortality risk per person per year per $1 \mu \mathrm{g} / \mathrm{m}^{3}$ of $\mathrm{PM}_{10}$. Using the $\mathrm{PM}_{10}$ particulate coefficient, the estimated $920 \mu \mathrm{g} / \mathrm{m}^{3}$ reduction in concentration for the Plancha (assuming the annual average difference is the same as the daily difference) would be expected to reduce annual mortality risks (annual probability of death) by 0.0078. The same calculation for the Kenya example would be a 0.01 reduction in annual mortality risk. These estimated risk reductions are very large, which in large part probably reflects the very imprecise knowledge of the relationship between particulate concentrations and health in these solid fuel burning households.

Using the same value of mortality risk reduction as for the previous example ( $\$ 22$ per change in annual mortality risk of 0.001 ), the annual willingness to pay per person would be about $\$ 209$ for Guatemala and \$190 for Kenya. This implied level of demand, based on willingness to pay, is also large relative to typical costs of improved stoves reported in Ballard-Tremeer and Mathee $(2000) .{ }^{20}$

The definition of demand, based on $\mathrm{B}^{*}$, also allows for the possibility that an intervention could have a positive impact on emissions but a negative impact on fuel efficiency. McCracken and Smith (1998), for example, concluded that the stove intervention in Guatemala substantially reduced emissions from wood burning but also reduced fuel efficiency and increased cooking time. The intervention thus generated a benefit from indoor air emissions reduction while imposing a cost in terms of reduced fuel efficiency.

\footnotetext{
${ }^{20}$ While based on information reported in the literature, it is emphasized that the numbers in Tables 2 and 3 are illustrative only - they are intended as examples of how to calculate the willingness to pay measure $\mathrm{B}^{*}$.
} 


\section{Household Shadow Values Pc* and Pa* for Morbidity Risks}

Table 3 provides an example of household demand for a reduction in morbidity in children using information from Pakistan. Existing data suggest that using a traditional stove increases the annual risk of acute lower respiratory infection (ALRI) by 2-10 times (Smith 2000). ${ }^{21}$ Using the lower bound odds ratio of 2, it could be estimated that the benefits of using an improved stove (or switching to other fuels) would be at least a 50 percent reduction in annual ALRI risk for children, of which pneumonia is the primary cause. Children under five in Pakistan are estimated to have an average of one case of pneumonia per child per year, of which some lead to death but most do not (ARCH 2000). As a rough estimate, then, the ALRI impact of an improved stove could be an average reduction of 0.5 cases of ALRI per under-five child per year.

Table 3 uses two approaches to value this risk reduction. The first, Table 3a, is based on medical treatment costs. As is reported in Table 1, the medical treatment cost of a case of non-severe pneumonia for a child under five in Pakistan is $\$ 4.87 .^{22}$ If a household actually sought treatment and paid these costs, then it is reasonable to conclude that the value to the household of treating the child (and presumably eliminating the direct morbidity effects of pneumonia and related mortality risks) would be at least as great as $\$ 4.87$. If a household did not seek treatment, then its implied value would be less than $\$ 4.87$. For households that do seek treatment, the 0.5 reduction in pneumonia cases per child per year suggests a lower bound value of $\$ 2.43$ per case, as reported in Table 3. For households that do not seek treatment, this figure would be lower. For a young child, the present value of this annual figure for a period of 5 years is $\$ 7.27$ at a 20 percent discount rate.

The second approach, which is shown in Table $3 \mathrm{~b}$, uses a combination of contingent valuation and benefits transfer. The starting point is an estimated value of $\$ 52.01$ to avoid a five-day episode of acute ARI symptoms among adults in Taiwan. ${ }^{23}$ Applying the ratio of the average income of households in the Taiwan sample and the average income of urban households in Pakistan, the benefit of avoiding a five-day episode of acute ARI symptoms in Pakistan is estimated at $\$ 6.24$, implying an annual value of risk reduction of $\$ 3.12$ per child. For a young child, the present value of this annual figure over 5 years would be $\$ 9.33$ at a 20 percent discount rate. ${ }^{24}$ These examples indicate that, if there are multiple children in a household, the household demand for reduced

\footnotetext{
${ }^{21}$ Smith and Mehta (2000) note that odds ratios differ for rural but not urban households in India, where relative risks for ARI (not ALRI) are reported to be 2.00 for rural households but just 1.22 for urban households.

${ }^{22}$ This is the estimated cost of treating a case of severe pneumonia at a public health facility in Pakistan if the WHO guidelines for treatment of pneumonia in children are followed. ARCH (2000) contains the data and calculations used for this estimate.

${ }^{23}$ A more recent study by Lui et al. (2000), which is included in Table 1, reports median willingness to pay to avoid a cold by mothers in Taiwan to be about $\$ 37$ for themselves and about $\$ 57$ for their children.

${ }^{24}$ The estimates in Table 3 for Pakistan are similar to those of Liu et al. (2000) for Taiwan, who found that a mother's willingness to pay (contingent valuation approach) to avoid a 5-day cold for her child was $\$ 57$, while the medical treatment costs associated with the same illness came to $\$ 22$.
} 
ALRI morbidity in children alone would seemingly justify an investment in an improved stove.

\section{Summary and Conclusions}

The main purpose of this paper has been to define household demand for interventions designed to reduce indoor air pollution. The household framework discussed in Section 2 expresses the correct measure of household demand based on willingness to pay, where demand can be decomposed into the sum of three terms: the child health effect, the adult health effect, and the direct consumption effect. The health effect components of demand are simply the physical health changes multiplied by the household's shadow prices for child and adult health. Section 3 then provided examples of estimating the health components of household demand using mortality and morbidity risk information related to improved stoves in Guatemala, Kenya, and Pakistan.

As the examples in Section 3 demonstrate, with adequate information on the individual components of demand, it is relatively simple to hazard an estimate of household willingness to pay for an intervention. At face value, the calculations reported in Section 3 suggest that household demand for interventions should be strong, with willingness to pay exceeding costs for common interventions like improved stoves.

The fact that such interventions are not being widely adopted by the 2 billion people still using solid fuels, however, indicates that the data on hand remain inadequate for correctly estimating household demand for indoor air pollution interventions. If such interventions are to be widely adopted, future applied research is clearly need on understanding and estimating household-level demand for indoor air pollution interventions. There are, for example, three key assumptions on which the results of the empirical analysis in Section 3 depend: (1) dose-response parameters for indoor air are identical to those for outdoor air, and are the same for children and adults; ${ }^{25}$ (2) household shadow prices for child and adult health are equal, and values from higher income countries can be transferred to lower income economies; ${ }^{26}$ and (3) households have adequate information to evaluate all the relationships between fuel use and health. None of these assumptions is likely to be entirely correct for most situations, and future research should focus on generating better information to refine these assumptions.

If future policies and projects are going to increase demand for indoor air pollution interventions, applied research is needed in five main areas. First, a better scientific understanding is clearly needed of the links between fuel use, indoor air concentrations, and key health outcomes, such as changes in mortality risk and changes in morbidity risk for children and adults. If scientists are not yet clear on such relationships, it is hard to imagine that households fully understand them and

\footnotetext{
${ }^{25}$ There is some evidence in yet-to-be-published research that the dose-response relationship for certain types of morbidity effects of indoor air pollution are different from dose-response parameters from outdoor air. The basic idea is that the dose-response relationship may be concave to the origin.

${ }^{26}$ Some initial work on adult values of changes in child health has been done by Liu et al. (2000) and Weaver et al. (1996). More research is clearly needed in this area.
} 
can incorporate them correctly into their decision making. We need to develop more-or-less continuous dose-response relationships and to generate separate curves for children and adults if the health impacts are age-specific. Knowing that households that rely on liquid fuels experience fewer cases of ALRI than those using solid fuels is useful, but it does not provide enough information to evaluate interventions that reduce the health impacts of solid fuels but do not replace them with liquid fuels.

Second, we must identify better ways to convey these relationships to households. Poor households must cope with a host of daily and seasonal problems across all the domains of their lives (social, economic, environmental, political, etc.). The lack of household information on fuels, air quality, and health is a valid reason for regarding existing health damages caused by indoor air pollution as an externality.

Third, more effort should be devoted to estimating the values households place on health risk reductions in general, with an explicit consideration of how poverty affects such values and how the existence of multiple health risks affect demand for risk reduction. To our knowledge, such valuation of health risk reduction has not been incorporated into household-level studies of interventions designed to reduce health risks for indoor air pollution. In the example in Section 3 , we assumed that the value of health for children is the same as that for adults, but there is no particular reason to believe that they are equal.

Fourth, a better understanding is needed of how specific interventions affect other household 'fixed' parameters as well as household production, time allocation, and consumption decisions. An intervention's impacts on emissions levels are important, as are changes in fuel efficiency, fuel preparation needs, and cooking times. Adopting an intervention will also have indirect effects on households. While this paper focused on household demand for the intervention, future research can also consider how adopting an intervention might alter fuel gathering, women's time allocations, purchases of health services, consumption of prepared foods by adults and children, and agricultural production.

And finally, while this paper has focused on demand quantity itself, future research is also needed to identify and evaluate policy options for increasing household demand for indoor air pollution interventions. Policies designed to reduce the direct purchase price of an intervention will increase demand to some extent, but little information exists on demand elasticities with respect to price to determine. Price changes result in movements along a demand schedule, but other policies will act to shift the entire demand schedule out, so that demand is higher at any given price. Understanding how to achieve an outward shift in demand schedules will require a thorough knowledge of the both the direct and indirect effects of an intervention, as well as their empirical magnitude. 


\section{References}

Alberini, A., et al. 1997. "Valuing health effects of air pollution in developing countries: the case of Taiwan." Journal of Environmental Economics and Management 34 (2): 107-26.

Alberini, A. and A. Krupnick. 2000. "Cost-of-illness and willingness-to-pay estimates of the benefits of improved air quality: evidence from Taiwan." Land Economics 76(1): 37-53.

ARCH. 2000. "The costs of antimicrobial resistance: a case study of childhood pneumonia in Pakistan." Applied Research on Child Health Project, Harvard Institute for International Development, Cambridge, MA.

Amacher, G.S., W. F. Hyde, K.R. Kanel. 1999. "Nepali fuelwood production and consumption: regional and household distinctions, substitutions and successful intervention." Journal of Development Studies 35: 138-63.

Amacher, G.S., W. F. Hyde, and B. R. Joshee. 1993. "Joint production and consumption in traditional households: fuelwood and crop residues in two districts in Nepal." Journal of Development Studies 30(1): 206-225.

Ballard-Tremeer, G., and Mathee, A. 2000. "Review of interventions to reduce the exposure of women and young children to indoor air pollution in developing countries." USAID/WHO Global Consultation on the Health Impact of Indoor Air Pollution and Household Energy in Developing Countries: Setting the Agenda for Action, May 3-4, 2000, Washington, DC.

Bruce, N. 1999. "Lowering exposure of children to indoor air pollution to prevent ARI: the need for information and action." Environmental Health Project Capsule Report Number 3, January 1999. Online. http://www.ehproject.org/Pubs/Capsule.htm.

Bruce, N., R. Perez-Padilla, and R. Albalak. 2000. "Indoor air pollution in developing countries: a major environmental and public health challenge." Bulletin of the World Health Organization 78(9): 1078-92.

Chemonics International and Associates. 1994. "Comparing environmental health risks in Cairo, Egypt." Report to USAID/Egypt.

Cline-Cole, R.A., Main, H.A.C., J.E. Nichol. 1990. "On fuelwood consumption, population dynamics and deforestation in Africa." World Development 18:513-527.

Cropper, M. and M. Freeman. 1991. "Environmental health effects.” In Braden, J.B., and C.D. Kolstad, eds. Measuring the Demand for Environmental Quality. Amsterdam: Elsevier Science Publishers.

de Janvry, A., M. Fafchamps, and E. Sadoulet. 1990. "Peasant household behaviour with missing markets: some paradoxes explained." The Economic Journal 101: 1400-1417.

Dickie, M. and S. Gerking. 1991. "Valuing reduced morbidity: a household production approach." Southern Economic Journal 57(3): 690-702.

Dockery, D., and A. Pope. 1996. "Epidemiology of acute health effects: summary of time-series studies." In Wilson, R., and J. Spengler (eds). Particles in Our Air: Concentrations and Health Effects. Boston: Harvard School of Public Health/Harvard University Press.

Donaldson, C. 1999. "Valuing the benefits of publicly-provided health care: does 'ability to pay' preclude the use of “willingness-to-pay'?” Social Science and Medicine 49: 551-63.

Ezzati, M., B. M. Mbinda, and D. M. Kammen. 2000. "Comparison of emissions and residential exposure from traditional and improved cookstoves in Kenya." Environmental Science and 
Technology 34 (4): 578-83.

Ezzati, M., and D. M. Kammen. 2000. "An exposure-response relationship for acute respiratory infections as a result of exposure to particulates from biomass combustion." In preparation.

Florig, H.K. 1993. "The benefits of air pollution reduction in China." Washington, DC: Resources for the Future.

Grossman, M. 1972. "On the Concept of Health Capital and the Demand for Health". Journal of Political Economy.

Hammitt, J.K., "Evaluating Contingent valuation of environmental health risks: the proportionality Test", AERE Newsletter, 20(2000): 14-19.

Harrington, W. and P. R. Portney. 1987. "Valuing the benefits of health and safety regulation." Journal of Urban Economics 22: 101-112.

Jacobson, L. 2000. "The Family as Producer of Health—An Extended Grossman Model". Journal of Health Economics: 19(5):611-37.

Jodha, N.S. 1986. "Common property resources and rural poor in dry regions of India." Economic and Political Weekly 21: 1169-81.

Kumar, S.K., and D. Hotchkiss. 1988. "Consequences of deforestation for women's time allocation, agricultural production, and nutrition in hill areas of Nepal." International Food Policy Research Institute, Research Report 69, October, 1988.

Larson, B.A., et al. 1999. "The Economics of air pollution health risks in Russia: a case study of Volgograd." World Development 27: 1803-19.

Lui, J.-T., et al. 2000. "Mother's willingness to pay for her own and her child's health: a contingent valuation study in Taiwan." Health Economics 9: 319-26.

Margulis, S. 1992. "Back of the envelope estimates of environmental damage costs in Mexico." World Bank Working Paper WPS 824.

McCracken, J.P., and K. R. Smith. 1998. "Emissions and efficiency of improved woodburning cookstoves in highland Guatemala." Environment International 24 (7) 739-47.

McCracken, J.P., et al. 1999. "Improved stove or inter-fuel substitution for decreasing indoor air pollution from cooking with biomass fuels in highland Guatemala?" Indoor Air '99.

Ostro, B., et al. 1996. "Air pollution and mortality: results from a study of Santiago, Chile." Journal of Exposure Analysis and Environmental Epidemiology 6(1): 97-114.

Pearce, D. 1996. "Economic valuation and health damage from air pollution in the developing world." Energy Policy 24 (7): 627-30.

Pitt, M. and M. Rosenzweig. 1985. "Health and nutrient consumption across and within farm households." Review of Economics and Statistics 67: 221-223.

Reddy, A.K.N., R. H. Williams, and T. B. Johansson. 1997. "Energy after Rio: prospects and challenges." United Nations Development Programme.

Satterthwaite, D. et al. 1996. The Environment for Children. London: Earthscan Publications Ltd.

Schwartz, J. 1994. "Air pollution and daily mortality: a review and meta analysis." Environmental Research 64: 36-52.

Simon, J., and S. Rosen. 2000. "The family health cycle: creating a context for maternal and child health interventions." HIID Development Discussion Paper 758. Cambridge, MA: Harvard Institute for International Development. 
Simon, N. B., et al. 1999. "Valuing morality reductions in India: a study of compensating wage differentials." Washington, DC: World Bank.

Singh, I., Squire, L., and J. Strauss, eds. 1986. Agricultural Household Models: Extensions, Applications and Policy. Baltimore: Johns Hopkins University Press.

Smith, K. 1999. "Indoor air pollution." Pollution Management In Focus Discussion Note 4, August 1999. Washington, DC: World Bank.

Smith, K., et al. 2000. "Indoor air pollution in developing countries and acute lower respiratory infections in children." Thorax 55: 518-32.

Smith, K. and Mehta, S. 2000. "The burden of disease from indoor air pollution in developing countries: comparison of estimates. USAID/WHO Global Consultation on the Health Impact of Indoor Air Pollution and Household Energy in Developing Countries: Setting the Agenda for Action, May 3-4, 2000, Washington, DC.

Strauss, J. 1988. "The effects of household and community characteristics on the nutrition of preschool children: evidence from rural Cote D'Ivoire." LSMSS Working Paper ISSN 02534517, No. 40. Washington, DC: The World Bank.

Thomas, D., J. Strauss, and M.-H. Henriques. 1990. "Child Survival, Height for Age and Household Characteristics in Brazil." Journal of Development Economics 33: 197-234.

Viscusi, W.K. 1993. "The Value of Risks to Life and Health." Journal of Economic Literature 31: 1912-1946.

Weaver, M., et al. 1996. "Willingness to pay for child survival: results of a national survey in Central African Republic." Social Science and Medicine 43 (6): 985-98.

WHO. 1997. "Health and environment in sustainable development: five years after the Earth Summit." Executive summary. Geneva: World Health Organization.

Wilson, R., and J. Spengler (eds). 1996. Particles in Our Air: Concentrations and Health Effects. Boston: Harvard School of Public Health/Harvard University Press.

World Bank. 1992. World Development Report 1992. New York: Oxford University Press.

World Bank. 1994a. "Indonesia environment and development: challenges for the future." Washington, DC: World Bank.

World Bank. 1994b. "Thailand: mitigating pollution and congestion impacts in a high growth economy." Washington, DC: World Bank.

World Bank. 1994c. "Chile: managing environmental problems-economic analysis of selected issues." Washington, DC: World Bank. 
Table 1: Sample values of health benefits

\begin{tabular}{|c|c|c|c|}
\hline Country & Value $^{(\mathbf{a})(\mathbf{b})}$ & Method & Source \\
\hline \multicolumn{4}{|l|}{ Mortality } \\
\hline India & VOSL $=\$ 153,000-\$ 358,000$ & $\begin{array}{l}\text { Compensating wage } \\
\text { differentials }\end{array}$ & Simon et al. (1999) \\
\hline China & VOSL $=\$ 45,547$ & Benefits transfer & $\begin{array}{l}\text { Florig (1993) in Pearce } \\
\text { (1996) }\end{array}$ \\
\hline $\begin{array}{l}\text { Thailand } \\
\text { (Bangkok) }\end{array}$ & VOSL $=\$ 336,000$ & $\begin{array}{l}\text { Compensating wage } \\
\text { differentials }\end{array}$ & $\begin{array}{l}\text { World Bank (1994b) in } \\
\text { Pearce (1996) }\end{array}$ \\
\hline $\begin{array}{l}\text { Indonesia } \\
\text { (Jakarta) }\end{array}$ & VOSL $=\$ 75,000$ & Benefits transfer & $\begin{array}{l}\text { World Bank (1994a) in } \\
\text { Pearce (1996) }\end{array}$ \\
\hline$\overline{\text { Egypt (Cairo) }}$ & VOSL $=\$ 62,021$ & Benefits transfer & $\begin{array}{l}\text { Chemonics International } \\
\text { and Associates (1994) in } \\
\text { Pearce (1996) }\end{array}$ \\
\hline $\begin{array}{l}\text { Mexico } \\
\text { (Mexico City) }\end{array}$ & VOSL $=\$ 75,000$ & Human capital approach & $\begin{array}{l}\text { Margulis (1992) in Pearce } \\
(1996)\end{array}$ \\
\hline \multicolumn{4}{|l|}{ Morbidity } \\
\hline Pakistan & $\begin{array}{l}\$ 4.87 \text { to treat a case of non- } \\
\text { severe, non-resistant bacterial } \\
\text { pneumonia in a child under } 5 \text { at } \\
\text { public clinics }\end{array}$ & $\begin{array}{l}\text { Cost of medical treatment } \\
\text { following WHO case } \\
\text { management guidelines } \\
\text { (clinic and pharmaceuticals } \\
\text { costs only) }\end{array}$ & ARCH (2000) \\
\hline China & $\mathrm{RAD}=\$ 1.29$ & Benefits transfer & $\begin{array}{l}\text { Florig (1993) in Pearce } \\
(1996)\end{array}$ \\
\hline Taiwan & $\begin{array}{l}\$ 37 \text { to prevent a cold of } 6.5 \\
\text { days for a mother; } \$ 57 \text { to } \\
\text { prevent a cold of } 5.4 \text { days } \\
\text { (mother's WTP for child) }\end{array}$ & Contingent valuation survey & Liu et al. (2000) \\
\hline Taiwan & $\begin{array}{l}\$ 30.73 \text { to avoid a 1-day episode } \\
\text { of acute respiratory symptoms } \\
\text { (more severe than a cold), } \\
\$ 52.01 \text { to avoid a 5-day episode }\end{array}$ & Contingent valuation survey & Alberini et al. (1997) \\
\hline Egypt (Cairo) & $\mathrm{RAD}=\$ 1.75$ & Benefits transfer & $\begin{array}{l}\text { Chemonics International } \\
\text { and Associates (1994) in } \\
\text { Pearce (1996) }\end{array}$ \\
\hline $\begin{array}{l}\text { Central } \\
\text { African } \\
\text { Republic } \\
\end{array}$ & $\begin{array}{l}\$ 15.30 \text { for drugs to treat a case } \\
\text { of child ARI }\end{array}$ & Contingent valuation survey & Weaver et al. (1996) \\
\hline $\begin{array}{l}\text { Chile } \\
\text { (Santiago) }\end{array}$ & $\mathrm{RAD}=\$ 9.95$ & Value of a work day & $\begin{array}{l}\text { World Bank (1994c) in } \\
\text { Pearce (1996) }\end{array}$ \\
\hline
\end{tabular}

(a) VOSL = Value of a Statistical Life

(b) RAD $=$ Restricted Activity Day 
Table 2: Examples of estimating the benefits of reduced mortality risks

\begin{tabular}{|c|c|c|c|c|c|c|c|}
\hline \multirow[t]{2}{*}{ Parameter } & \multirow[t]{2}{*}{ Units } & \multicolumn{2}{|c|}{ General case } & \multicolumn{2}{|c|}{ Guatemala } & \multicolumn{2}{|c|}{ Kenya } \\
\hline & & Traditional & Improved & 3-Stone & Plancha & 3-Stone & Improved \\
\hline Monitored pollutant & & TSP & TSP & $\mathrm{PM}_{2.5}$ & $\mathrm{PM}_{2.5}$ & TSP & TSP \\
\hline Emissions during cooking & $: \mathrm{g} / \mathrm{m}^{3}$ & 4,500 & 2,000 & 27,200 & 450 & 3,503 & 1,822 \\
\hline Cooking time per day & Hours & 6 & 6 & $5^{(\mathrm{a})}$ & $6.5^{(\mathrm{a})}$ & 7.8 & 7.8 \\
\hline TSP during non-cooking & $: \mathrm{g} / \mathrm{m}^{3}$ & 100 & 100 & n.a. & n.a. & $4,496^{(\mathrm{c})}$ & 1,034 \\
\hline Non-cooking time & Hours & 18 & 18 & n.a. & n.a. & 7.2 & 7.2 \\
\hline $\begin{array}{l}\text { Average daily concentration of } \\
\text { monitored pollutant }\end{array}$ & $: \mathrm{g} / \mathrm{m}^{3}$ & 1,200 & 575 & & 122 & 2,487 & 902 \\
\hline $\begin{array}{l}\mathrm{PM}_{10} \text { or } \mathrm{PM}_{2.5} \text { as } \% \text { of monitored } \\
\text { pollutant }\end{array}$ & range $0-1$ & 0.3 & 0.3 & 1.0 & 1.0 & 0.63 & 0.35 \\
\hline Average daily $\mathrm{PM}_{10}$ or $\mathrm{PM}_{2.5}$ & $: \mathrm{g} / \mathrm{m}^{3}$ & 360 & 172.5 & 1,102 & 180 & 1,567 & 316 \\
\hline Average annual $\mathrm{PM}_{10}$ or $\mathrm{PM}_{2.5}$ & $: \mathrm{g} / \mathrm{m}^{3}$ & 360 & 172.5 & 1,102 & 180 & 1,567 & 316 \\
\hline $\begin{array}{l}\text { Change in annual average } \mathrm{PM}_{10} \\
\text { with improved stove }\end{array}$ & $: \mathrm{g} / \mathrm{m}^{3}$ & & -187.5 & & -922 & & $-1,251$ \\
\hline $\begin{array}{l}\text { Particulate coefficient }=\text { change } \\
\text { in annual mortality risk } / 1: \mathrm{g} \\
\text { change in annual average } \mathrm{PM}_{10}\end{array}$ & $\begin{array}{l}\text { See def. of } \\
\text { particulate } \\
\text { coefficient }\end{array}$ & & $8.5 \mathrm{E}-06$ & & $8.5 \mathrm{E}-06$ & & $8.5 \mathrm{E}-06$ \\
\hline Change in annual mortality risk & & & -0.0016 & & -0.0078 & & -0.0106 \\
\hline $\begin{array}{l}\text { Value of } 0.001 \text { change in } \\
\text { mortality risk for developd } \\
\text { country population }\end{array}$ & \$US & & 3,000 & & 3,000 & & 3,000 \\
\hline $\begin{array}{l}\text { Average household income level } \\
\text { of group used to estimate VOSL }\end{array}$ & $\$ U S$ & & 40,000 & & 40,000 & & 40,000 \\
\hline $\begin{array}{l}\text { Average income level of } \\
\text { developing country household } \\
\text { using solid fuels }\end{array}$ & \$US & & 300 & & 357 & & 238 \\
\hline Income ratio & range $0-1$ & & 0.008 & & 0.009 & & 0.006 \\
\hline $\begin{array}{l}\text { Developing country } \\
\text { approximated value of marginal } \\
\text { risk reduction }\end{array}$ & $\$$ US & & 23 & & 27 & & 18 \\
\hline $\begin{array}{l}\text { Annual benefits of mortality risk } \\
\text { (reduction due to improved } \\
\text { stove) }\end{array}$ & $\begin{array}{l}\text { \$US per } \\
\text { person }\end{array}$ & & 36 & & 209 & & 190 \\
\hline $\begin{array}{l}\text { Total exposed individuals in } \\
\text { household }\end{array}$ & $\begin{array}{l}\text { Number of } \\
\text { individuals }\end{array}$ & & 4 & & 4 & & 4 \\
\hline $\begin{array}{l}\text { Annual benefits of mortality risk } \\
\text { reduction due to improved stove }\end{array}$ & $\begin{array}{l}\text { \$US per } \\
\text { household }\end{array}$ & & 143 & & 838 & & 759 \\
\hline $\begin{array}{l}\text { Cost of improved stove (upper } \\
\text { end of range) }\end{array}$ & $\begin{array}{l}\text { \$US per } \\
\text { household }\end{array}$ & & 21 & & 21 & & 21 \\
\hline $\begin{array}{l}\text { Net benefits in year } 1 \text { of } \\
\text { mortality risk reduction }\end{array}$ & $\begin{array}{l}\text { \$US per } \\
\text { household }\end{array}$ & & 122 & & 817 & & 738 \\
\hline Source & & Bruce ( & 1999) & $\begin{array}{l}\text { McCracken } \\
\text { (1998) and } \\
\text { al. (1999) }\end{array}$ & $\begin{array}{l}\text { nd Smith } \\
\text { cCracken et }\end{array}$ & $\begin{array}{l}\text { Ezzati, Mb } \\
\text { Kammen }\end{array}$ & $\begin{array}{l}\text { da, and } \\
00 \text { ) }\end{array}$ \\
\hline
\end{tabular}

(a) Assumes two cooked meals per day. The Plancha requires longer cooking times than a traditional stove.

(b) Viscusi (1993) cites $\$ 3$ million as a reasonable estimate of the value of a statistical life (VOSL) in the U.S. A 0.001 change in mortality risk would then be valued at $\$ 3,000$.

(c) Emissions were found to be highest during non-cooking times, when the fire was left to smolder. 
Table 3: Examples of estimating the benefits of reduced ARI morbidity risks in Pakistan

\begin{tabular}{|c|c|c|}
\hline \multicolumn{3}{|c|}{ 3a: Example using treatment costs } \\
\hline Parameter & Units & Value \\
\hline $\begin{array}{l}\text { Pneumonia per child per } \\
\text { year (age 2-59 months) }\end{array}$ & Cases & 1 \\
\hline $\begin{array}{l}\text { Reduction in ALRI } \\
\text { morbidity per year due to } \\
\text { intervention }\end{array}$ & $\begin{array}{c}\text { Cases/ } \\
\text { child }\end{array}$ & 0.50 \\
\hline $\begin{array}{l}\text { Medical treatment cost per } \\
\text { non-severe pneumonia case }\end{array}$ & US \$ & 4.87 \\
\hline $\begin{array}{l}\text { Proportion of households } \\
\text { seeking and paying for } \\
\text { treatment }\end{array}$ & $\begin{array}{c}\text { Range } \\
0-1\end{array}$ & 0.5 \\
\hline \begin{tabular}{|l} 
Average WTP for ARI \\
reduction (lower bound)
\end{tabular} & US \$ & 2.43 \\
\hline $\begin{array}{l}\text { Present value of benefits } \\
\text { per child during years } 0-5 \\
(20 \% \text { discount rate) }\end{array}$ & US \$ & 7.27 \\
\hline $\begin{array}{l}\text { Average number of exposed } \\
\text { children per household }\end{array}$ & Persons & 3 \\
\hline $\begin{array}{l}\text { Present value of benefits } \\
\text { per household while } \\
\text { children are }<5\end{array}$ & US \$ & 21.81 \\
\hline
\end{tabular}

\begin{tabular}{|c|c|c|}
\hline Parameter & Units & Value \\
\hline $\begin{array}{l}\text { Pneumonia per child per } \\
\text { year (age } 2-59 \text { months) }\end{array}$ & Cases & 1 \\
\hline $\begin{array}{l}\text { Reduction in ALRI } \\
\text { morbidity per year due to } \\
\text { intervention }\end{array}$ & $\begin{array}{c}\text { Cases/ } \\
\text { child }\end{array}$ & 0.50 \\
\hline $\begin{array}{l}\text { Benefit of avoiding a 5-day } \\
\text { episode of acute respiratory } \\
\text { symptoms in Taiwan } \\
\text { (adults) }\end{array}$ & US \$ & 52.01 \\
\hline $\begin{array}{l}\text { Average income of } \\
\text { households used to estimate } \\
\text { morbidity value }\end{array}$ & US \$ & 28,260 \\
\hline $\begin{array}{l}\text { Average income of urban } \\
\text { households in Pakistan }\end{array}$ & US \$ & 3,298 \\
\hline Income ratio & $\begin{array}{c}\text { Range } \\
0-1\end{array}$ & 0.12 \\
\hline $\begin{array}{l}\text { Inferred benefit of avoiding } \\
\text { a 5-day episode of acute } \\
\text { respiratory symptoms in } \\
\text { Pakistan }\end{array}$ & US \$ & 6.24 \\
\hline $\begin{array}{l}\text { Value of annual ARI risk } \\
\text { reduction per year per child }\end{array}$ & US \$ & 3.12 \\
\hline $\begin{array}{l}\text { Present value of benefits per } \\
\text { child during years } 0-5(20 \% \\
\text { discount rate) }\end{array}$ & US \$ & 9.33 \\
\hline $\begin{array}{l}\text { Average number of exposed } \\
\text { children per household }\end{array}$ & Persons & 3 \\
\hline $\begin{array}{l}\text { Present value of benefits per } \\
\text { household while children } \\
\text { are }<5\end{array}$ & US \$ & 29.07 \\
\hline
\end{tabular}

Sources: ARCH (2000) and Table 1. 